\title{
Secretin, a Stimulus for Duodenal and Pancreatic "Gastrin" Release: Possible Pathogenetic Significance in Zollinger-Ellison (ZE) Syndrome
}

\author{
Frederic E. Eckhauser, M.D., ${ }^{* 1}$ Aaron I. Vinik, M.D., †ichael McLeod, M.D.,* \\ Vicki Porter-Fink, M.S., * and Richard G. Fiddian-Green, M.D.* \\ Departments of $*$ Surgery and + Medicine, University of Michigan Medical Center and \\ The Veterans Administration Medical Center, Ann Arbor, Michigan 48109
}

Presented at the Annual Meeting of the Association for Academic Surgery, Great Gorge, New Jersey, November 11-14, 1979

\begin{abstract}
Ex vivo hemoperfused pancreaticoduodenal preparations from dogs have been used to study intraluminal and circulatory patterns of release of immunoreactive gastrin under basal conditions and after secretin stimulation. Bidirectional release of immunoreactive gastrin was maximal at $3 \mathrm{~J} / \mathrm{min}$ secretin infusion, and release into pancreatic and duodenal juice exceeded that into portal venous blood. Molecular sieving chromatography of peptides with gastrin-like immunoreactivity recovered from duodenal and pancreatic juice indicated a single species of a molecular size equivalent to $\mathrm{CCK}^{8}$ and smaller than minigastrin (G-14). The exact identity has not been defined. This study demonstrates that secretin stimulates release of gastrin-like peptides into blood and lumen of extra-antral gastrin-producing tissues in the dog. Unidirectional gastrin release patterns from gastrinoma tissue may explain the paradoxical increase in plasma gastrin levels in response to secretin in patients with gastrinomas (ZollingerEllison syndrome).
\end{abstract}

\section{INTRODUCTION}

Seventy-five years have elapsed since Edkins first reported that extracts of antral mucosa stimulated gastric acid secretion [6]. Gregory and Tracy are credited with the isolation and physicochemical characterization of gastrin in pure form [9]. For many years gastrin was viewed as a hormone originating primarily from the gastric antrum, but precise localization of the site(s) of release has not been demonstrated.

Recent observations in man and dog suggest that gastrin may be elaborated by extraantral tissues [22, 33]. The greatest proportion of mucosal gastrin in both species is localized to the gastric antrum, with diminishing tissue concentrations in the

\footnotetext{
${ }^{1}$ Address reprint requests to Frederic E. Eckhauser, M.D., Department of Surgery, University of Michigan Medical Center, 1405 E. Ann Street, Ann Arbor, Michigan 48109.
}

small intestine from duodenum to ileum [33]. Although little is known about the ontogeny of gastrin-producing cells, they have been identified prenatally in man and rat $[17,18,21]$. Gastrin release into both the gut lumen and the portal circulation has been documented, but to date there is equivocal evidence of "true" gastrin-producing cells in adult pancreas or of gastrin release into pancreatic juice.

Gastrin release is mediated through complex neuroendocrine and paracrine servomechanisms. Several hormones, including secretin and somatostatin, are effective in suppressing gastrin release $[7,10,12]$. Acidification of both the antrum and the duodenum has been shown to suppress the release of gastrin from the gastric antrum, presumably via different mechanisms $[2$, $8,11,20]$. Secretin has been implicated as the major mediator of the latter servomechanism, and appears to act both by suppressing the release of antral gastrin 
and by blocking the action of gastrin on oxyntic or parietal cells $[12,16]$. The administration of exogenous secretin normally decreases fasting levels of immunoreactive gastrin in dogs and in humans with "usual" forms of duodenal ulcer disease [28]. The increase in fasting serum gastrin levels observed following the administration of secretin to patients with Zollinger-Ellison syndrome remains a paradox $[16,28]$. Although the precise mechanism underlying this response is unknown, a direct stimulating effect of secretin upon gastrinoma cells has been postulated [16].

Recent data suggest that immunoreactive gastrin is released into the antral and duodenal lumens of cats following electrical vagal stimulation or topical application of acetylcholine [30]. In vitro studies have further shown that secretin may inhibit luminal release of immunoreactive gastrin from the antrum of the dog [7].

The present studies were designed to test the following hypotheses: first, that immunoreactive gastrin in the dog may be released from extra-antral tissues, notably pancreas and duodenum; second, that se- cretin may stimulate the release of gastrin from extra-antral tissues in the dog; and third, that bidirectional release into the portal circulation and lumens of pancreas and duodenum following secretin infusion may be a normal phenomenon.

\section{MATERIALS AND METHODS}

\section{Specimen Preparation and Perfusion Technique}

Pancreaticoduodenal preparations were obtained from six mongrel dogs (20-25 kg body weight) using the technique of Ritchie and Hardcastle [25]. The preparation was maintained at normothermia and perfused through the superior mesenteric artery and one branch of the splenic artery. Venous effluent was collected from the portal vein. An 8- to $10-\mathrm{cm}$ juxtapancreatic segment of duodenum was isolated, with preservation of the inferior and superior pancreaticoduodenal veins. The ampulla of Vater was identified through a $3-\mathrm{cm}$ duodenotomy, and the pancreatic duct cannulated with a fine metal probe. The extraduodenal portion of the pancreatic duct was isolated, then

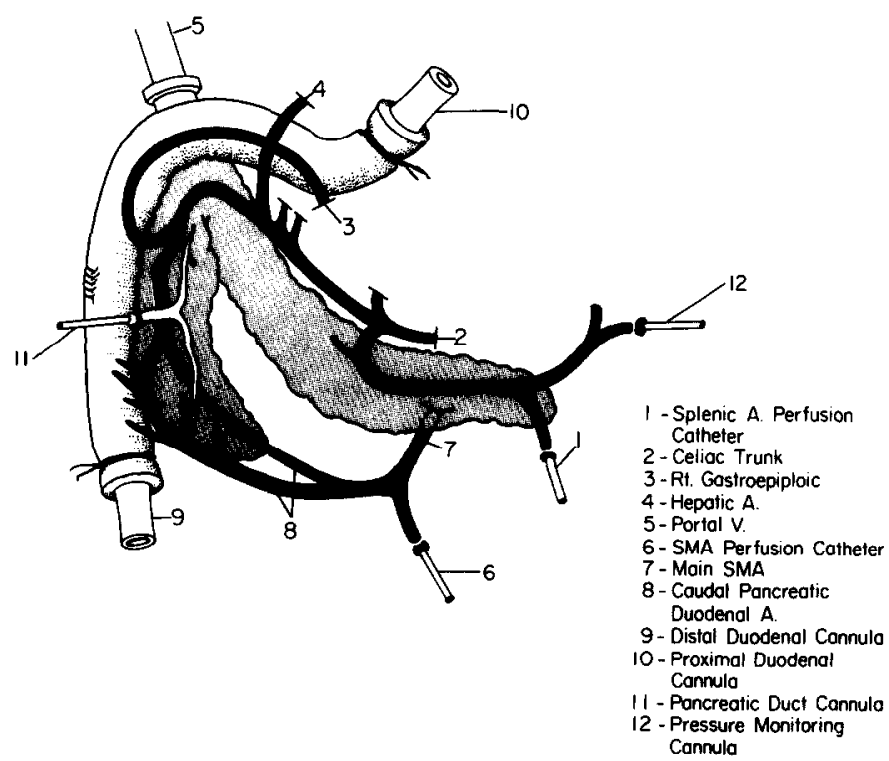

FIG. 1. The anatomy of the ex vivo pancreaticoduodenal preparation. 


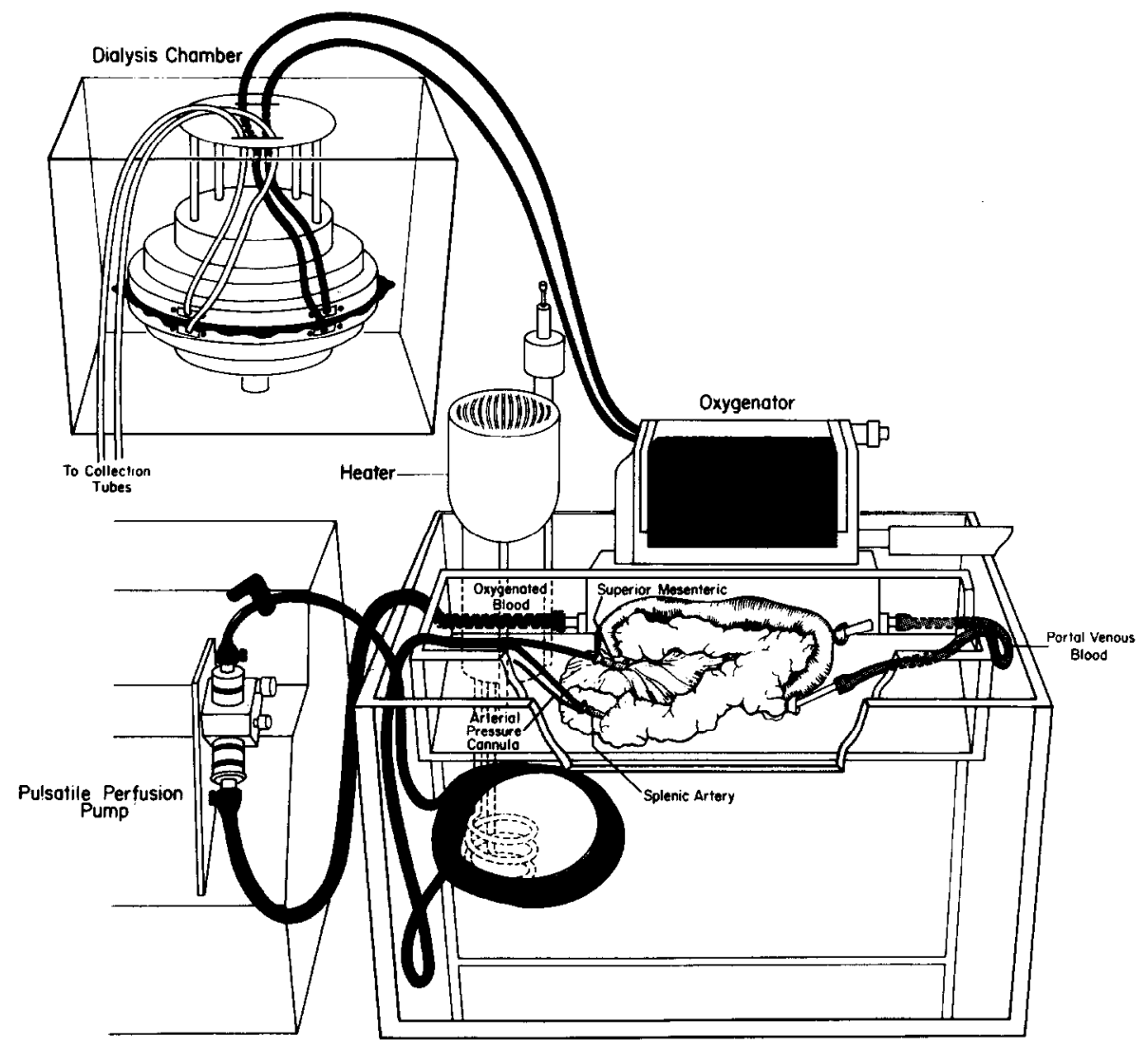

FIG. 2. The entire perfusion system with oxygenator/reservoir, in-line dialysis unit, and pulsatile perfusion pump.

cannulated with $18.5-\mathrm{G}$ medical-grade polyethylene tubing, and the proximal portion was ligated. Accessory pancreatic ducts were suture ligated when identified. Flexible collection tubes were secured at the proximal and distal ends of the duodenum to permit perfusion of the isolated bowel segment and collection of specimens. The final preparation is illustrated in Fig. 1.

A closed-circuit perfusion apparatus (Fig. 2), similar to that of Vaysse and colleagues [31], was modified by the addition of an in-line dialysis unit (Technicon heated dialyzer, Model 1). Both the perfusion chamber and the dialysis unit were primed with an albumin-containing perfusate solution, ${ }^{2}$

${ }^{2}$ Perfusate composition: $\mathrm{Na}^{+}, 127 \mathrm{meq} / \mathrm{liter} ; \mathrm{Cl}^{-}$, 105 meq/liter; $\mathrm{HCO}_{3-}, 40$ meq/liter; $\mathrm{Ca}^{2+}, 5$ meq/liter; $\mathrm{K}^{+}, 3.5 \mathrm{meq} / \mathrm{liter} ; \mathrm{Mg}^{2+}, 2 \mathrm{meq} / \mathrm{liter} ; \mathrm{PO}_{4}, 2 \mathrm{meq} /$ and the final hematocrit in the reservoir was adjusted to $25-30 \%$ by adding autologous red blood cells. Blood perfusate and stock perfusate were withdrawn from the system at equal rates $(28-32 \mathrm{ml} / 30 \mathrm{~min}$ through a mixing coil into the dialysis chamber and filtered through a Gelman 1.2$\mu \mathrm{m}$ metricel membrane at a rate approximating the intake flow. Damaged red blood cells and free hemoglobin were removed from circulation and half the blood perfusate volume was replaced with fresh stock solution with each passage through the dialyzer. A rotating disk oxygenator

litcr; $\mathrm{SO}_{4}, 1$ meq/liter; bovine serum albumin (BSA), $4 \mathrm{~g} \%$; glucose, $150 \mathrm{mg} \%$; and mannitol to adjust the final osmotic pressure to 315 mosmoles/liter. One thousand units of aqueous heparin was added per liter of perfusate solution. 
(Sarnes, Inc., Ann Arbor, Michigan), supplied with a $95 \% \mathrm{O}_{2}-5 \% \mathrm{CO}_{2}$ gas mixture, served as the blood reservoir. The preparation was perfused at a constant blood flow (CBF) of $20-25 \mathrm{ml} / \mathrm{min}$ using a pulsatile infusion pump (Harvard Products, Model 1405). Arterial and portal pressures were monitored continuously and recorded (Hewlett-Packard multichannel recorder, Model 7754A). The $\mathrm{pH}, p \mathrm{O}_{2}$, and $p \mathrm{CO}_{2}$ were analyzed ( $\mathrm{pH}$ blood gas analyzer, Radiometer, Copenhagen) and corrected at hourly intervals as needed.

\section{Experimental Procedure}

The duodenal segment was perfused continuously at $2 \mathrm{ml} / \mathrm{min}$ with lactated Ringers solution containing phenol red indicator, $0.6 \%$. Addition of the dye indicator permitted rapid assessment of the luminal $\mathrm{pH}$; change from the acid orange range signified contamination by alkaline pancreatic secretions. Duodenal effluent was collected on ice every $10 \mathrm{~min}$, the volume recorded, and a sample obtained for subsequent gastrin assay. Each sample was boiled for $10 \mathrm{~min}$, quick-frozen in a dry ice-alcohol bath, and stored at $-20^{\circ} \mathrm{C}$. Samples of dialysate were collected and processed in a similar fashion.

Following a 30-min equilibration period, basal samples were obtained from the portal vein (PV), pancreatic duct (PD), and duodenum (D). Trasylol (Aprotinin, Mobay Chemicals, New York) was added to pancreatic juice at a volume ratio of 1:5 and the samples were quick frozen.

Boots secretin (Boots Co. Ltd., Nottingham, England) was infused at $1 \mathrm{U} / \mathrm{min}$. Samples for immunoreactive gastrin assay were collected from portal vein, pancreatic duct, and duodenum at intervals of $1,3,5$, 10,20 , and $30 \mathrm{~min}$. After $30 \mathrm{~min}$ of infusion, the dose of secretin was increased to $3 \mathrm{U} /$ $\mathrm{min}$, and after another $30 \mathrm{~min}$, to $5 \mathrm{U} / \mathrm{min}$. Samples were collected at the same intervals as above during each secretin infusion period and were processed rapidly and quick-frozen for assay at a later date. At the conclusion of the experiment 0.5 - to $1.0 \mathrm{~g}$ biopsy samples of pancreas and duodenum were obtained. These specimens were boiled in distilled water for $10 \mathrm{~min}$, and after removing the tissue plug, the extract was quick-frozen.

In order to calculate the amount of immunoreactive gastrin lost from the system by dialysis, an additional experiment was performed. Thirty nanograms of synthetic heptadecapeptide gastrin (G-17) was added to a perfusion system not containing an organ. The final concentration of gastrin in the system was $100 \mathrm{pg} / \mathrm{ml}$. Blood flow and reservoir volume remained constant throughout the procedure. Average percentage cumulative losses of immunoreactive gastrin were calculated by dividing the amount of gastrin measured in the dialysate per 30min collection period by the total gastrin measured in the system (amount lost and that remaining) and multiplying by 100 .

\section{Immunoreactive Gastrin Assay and Validation}

Immunoreactive gastrin was measured by a radioimmunoassay previously described [32]. Antiserum raised against synthetic human gastrin (SHG 17-I) demonstrated 1\% cross-reactivity with $\mathrm{CCK}^{8}$ (courtesy of $\mathrm{Dr}$. M. Ondetti, Squibb Pharmaceuticals), $0.003 \%$ with tetragastrin, and $0.003 \%$ with cerulean using ${ }^{125}$ I-gastrin 17-I as a tracer.

Samples of juice from the duodenum and pancreatic duct were chromatographed on Sephadex G-50 superfine columns (pH 8.0; flow rate, $4.0 \mathrm{ml} / \mathrm{hr}$; column, $100 \times 1.0 \mathrm{~cm}$ ). Affinity chromatography using gastrin antiserum $\mathrm{G}_{2}$ conjugated to Sepharose $4 \mathrm{~B}$ was performed on samples of pancreatic and duodenal juice. The bound fractions were desorbed with $0.1 \mathrm{M}$ acetic acid at $\mathrm{pH} 2.5$. These samples were lyophillized, reconstituted in assay buffer, and assayed for immunoreactive gastrin as described previously. In a control experiment, ${ }^{125}$ Igastrin 17-I was applied to the column and eluted in the same manner. 


\section{Statistical Analysis}

Results are expressed as the mean \pm standard error. The standard $t$ test was used to analyze the data for significant differences between the means. Differences with a $P$ value of less than 0.05 were considered significant.

\section{RESULTS}

\section{Evidence of Immunoreactive Gastrin}

Release into Duodenal and Pancreatic

Juice

Duodenum. The infusion rate of lactated Ringers-phenol red indicator solution into the duodenal segment was manipulated during basal and stimulated periods to maintain a minimum effluent volume of 1-2 $\mathrm{ml} / \mathrm{min}$. The average cumulative $30-\mathrm{min}$ basal volume $(67 \pm 11 \mathrm{ml})$ was not significantly different from the volumes collected at 1,3 , and $5 \mathrm{U} / \mathrm{min}$ secretin infusion $(69 \pm 11,59 \pm 10$, and $79 \pm 10 \mathrm{ml}$, respectively; $P$ NS). The cumulative basal release of immunoreactive gastrin into duodenal juice was $2225 \pm 334 \mathrm{pg} / 30 \mathrm{~min}$. Stim-

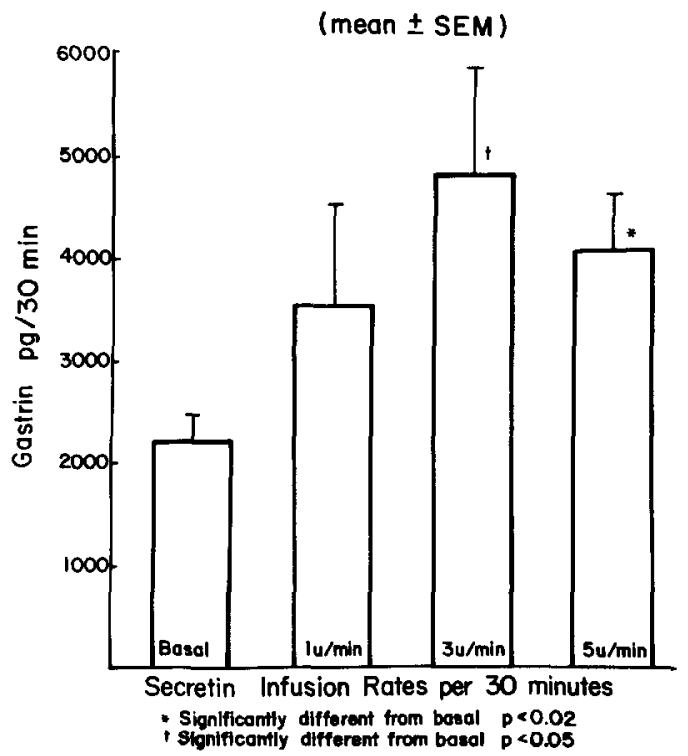

Fig. 3. The effects of stepwise increases in secretin infusion upon the average cumulative gastrin release into the duodenal lumen per 30 -min collection period.

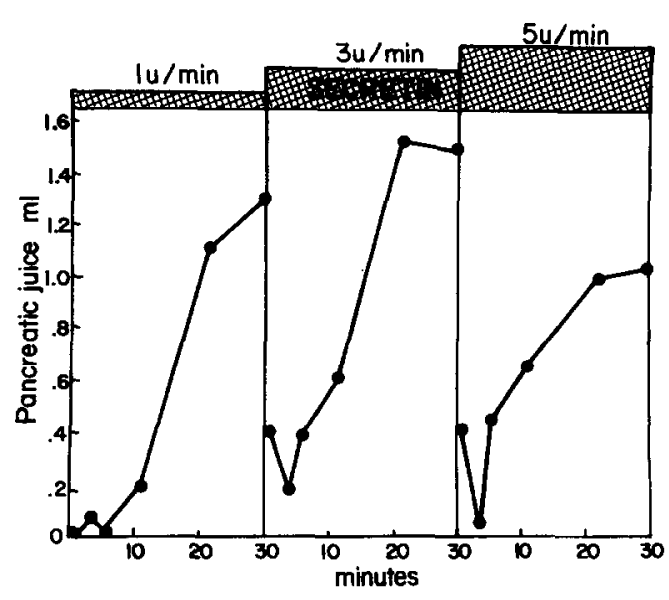

FIG. 4. The flow response patterns of pancreatic juice to increases in secretin dosage.

ulation with $1 \mathrm{U} / \mathrm{min}$ secretin increased this value to $3622 \pm 902 \mathrm{pg}$. Infusion of $3 \mathrm{U} / \mathrm{min}$ secretin significantly $(P<0.05)$ increased the secretion to $4949 \pm 1072 \mathrm{pg}$, and 5 $\mathrm{U} / \mathrm{min}$ secretin infusion caused no further increase $(4175 \pm 583 \mathrm{pg})$. Gastrin release at $5 \mathrm{U} / \mathrm{min}$ secretin infusion was, however, significantly $(P<0.02)$ different from basal (Fig. 3).

Pancreas. Spontaneous flow from the pancreatic duct was not observed in the basal state. In response to secretin infusion, the average cumulative flow rose from $2.7 \pm 0.7 \mathrm{ml}$ at $1 \mathrm{U} / \mathrm{min}$ of secretin to $4.6 \pm 1.2 \mathrm{ml}$ at $3 \mathrm{U} / \mathrm{min}$ and fell to 3.7 $\pm 0.8 \mathrm{ml}$ at $5 \mathrm{U} / \mathrm{min}$. These values were not significantly different. In each instance there was a delay lasting about $10 \mathrm{~min}$ before the secretory response to secretin was observed (Fig. 4). Patterns of gastrin release were similar to those of juice flow (Fig. 5). There was no basal secretion. During infusion of $1 \mathrm{U} / \mathrm{min}$ secretin the average cumulative release of immunoreactive gastrin was $128 \pm 40 \mathrm{pg}$. With secretin infusion rates of 3 and $5 \mathrm{U} / \mathrm{min}$, $202 \pm 48$ and $138 \pm 9.0 \mathrm{pg}$ were released, respectively, values which were not significantly different from that with the 1 $\mathrm{U} / \mathrm{min}$ infusion. Regression analysis of the rate of release of immunoreactive gastrin into pancreatic juice ( $\mathrm{pg} / \mathrm{min}$ ) versus the 


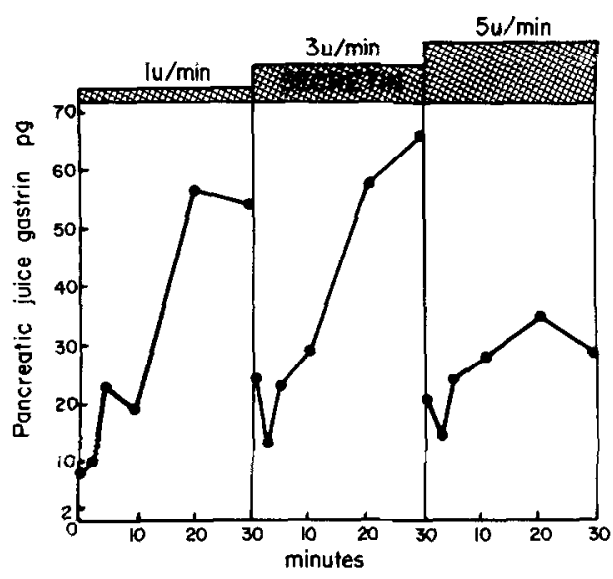

FIG. 5. The gastrin release patterns in pancreatic juice in response to increases in secretin dosage.

rate of pancreatic juice flow $(\mathrm{ml} / \mathrm{min})$ yielded a correlation coefficient of $0.83(P<0.001)$, signifying that the rate of pancreatic gastrin release was flow dependent (Fig. 6).

By extraction, immunoreactive gastrin was recovered from tissue samples of duodenum and pancreas. In a limited number of experiments, the mean immunoreactive gastrin recovered from samples of duodenum $(N=3)$ was $1690 \pm 235 \mathrm{pg} / \mathrm{g}$ and that from pancreas $(N=2)$ was $706 \pm 214 \mathrm{pg} / \mathrm{g}$.

\section{Evidence for Immunoreactive Gastrin}

Release into the Portal Vein in Response to Secretin Infusion

By calculation of dialysate gastrin losses, there was an average of $7.8 \%$ total gastrin in the system lost per 30-min collection period. This necessitated correction of each portal vein gastrin concentration by a factor of $0.03 \%$. The average basal gastrin concentration was $49.8 \pm 4.8 \mathrm{pg} / \mathrm{ml}$. In response to 1,3 , and $5 \mathrm{U} / \mathrm{min}$ secretin infusion, these values rose to $52.7 \pm 3.5,65.7 \pm 2.9$, and $77.1 \pm 3.2 \mathrm{pg} / \mathrm{ml}$ (Fig. 7). The average gastrin concentrations at 3 and $5 \mathrm{U} / \mathrm{min}$ secretin infusion were significantly $(P<0.01)$ different from basal and the values with the infusion of $1 \mathrm{U} / \mathrm{min}$. In addition, the gastrin values at all secretin infusion rates were significantly ( $P<0.01$ ) different from each other. Because gastrin accumulated in a closed system without active removal, portal vein values alone reffect neither the total mass secreted nor changes due to increasing secretin doses. Hence, the average net increment in portal vein immunoreactive gastrin content over and above the preceding level was calculated. The incremental changes in portal venous gastrin release are compared with those measured in duodenal and pancreatic juice, and are depicted in Table 1. Similar release patterns over time were observed in all six experiments.

\section{Isolation and Characterization of \\ Immunoreactive Gastrin Released from \\ Different Tissues}

When pancreatic juice containing $540 \mathrm{pg}$ of immunoreactive gastrin was applied to an affinity column containing an antiserum covalently bound to Sepharose, $44 \%$ of that gastrin was bound and eluted with $0.1 M$ acetic acid. On rechromatography of this material, $100 \%$ was bound. Fifty-six percent of the gastrin in duodenal juice was bound by the column. The column capacity was estimated to be $250 \mathrm{pg}$ and the unbound fraction represented an over-

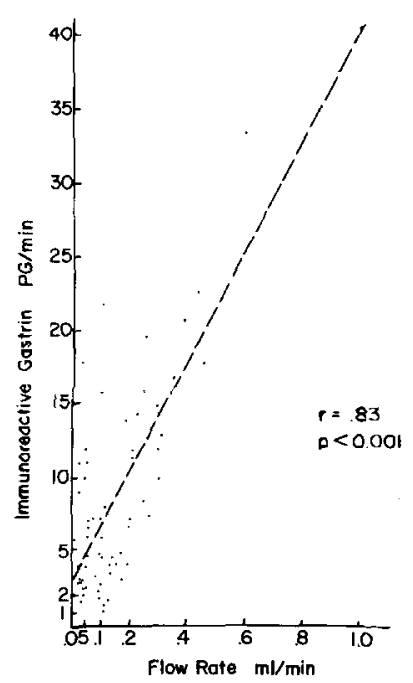

Fio. 6. Regression curve of the rate of pancreatic juice flow versus the rate of gastrin release into pancreatic juice. 
(mean \pm SEM)

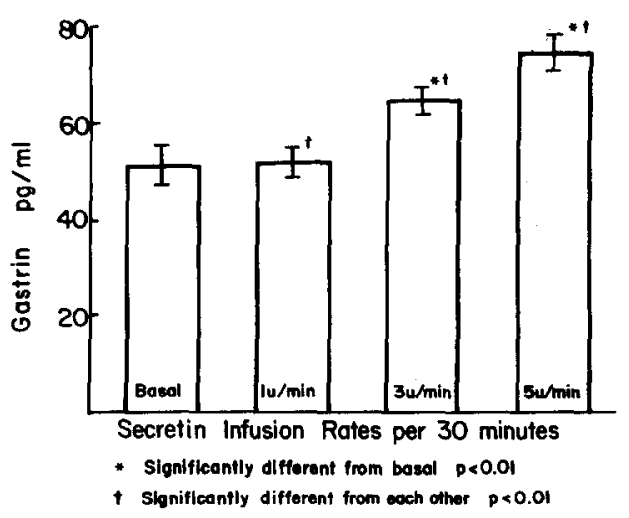

Fig. 7. The effect of secretin infusion upon the average portal vein immunoreactive gastrin concentrations.

load of the capacity of the column to bind gastrin (Fig. 8).

Immunoreactive gastrin in both pancreatic and duodenal juice was detected using a Cterminal reacting antiserum and duodenal juice eluted on Sephadex G-50 columns as a peptide equivalent in molecular weight to CCK. ${ }^{8}$ This peptide did not react with a $\mathrm{NH}_{2}$-directed gastrin antiserum, suggesting that it contained the $\mathrm{C}$-terminal portion of gastrin or $\mathrm{CCK}^{8}$ Rechromatography of the gastrin in pancreatic juice obtained by acetic acid elution of that bound to the affinity column resulted in a single peak again equivalent in molecular weight to $\mathrm{CCK}^{8}$ (Fig. 9).

Portal vein IG eluted on Sephadex G-50 predominantly as $\mathrm{G} 34$, with a lesser fraction corresponding to $\mathrm{G} 17$ and smaller peptides (Fig. 10).

\section{DISCUSSION}

The use of an ex vivo pancreaticoduodenal perfusion system facilitates study of the mechanism(s) of circulatory and luminal immunoreactive gastrin (IG) release from extra-antral tissues, and avoids many of the problems of in vivo systems. The placement of separate collection cannulae into the duodenal and pancreatic duct lumens allows observation of the dynamics of
TABLE 1

Average Net Changes in Luminal and Portal VENOUS RELEASE OF IMMUNOREACTIVE GASTRIN (pg/30 min)

\begin{tabular}{lccc}
\hline & $\begin{array}{c}\text { Portal } \\
\text { vein }\end{array}$ & Duodenum & $\begin{array}{c}\text { Pancreatic } \\
\text { duct }\end{array}$ \\
\hline $1 \mathrm{U} / \mathrm{min}$ & 870 & 3622 & $128^{a}$ \\
secretion & $(+6 \%)$ & $(+63 \%)$ & \\
$3 \mathrm{U} / \mathrm{min}$ & 3900 & 4949 & 202 \\
secretion & $(+25 \%)$ & $(+37 \%)$ & $(+58 \%)$ \\
$5 \mathrm{U} / \mathrm{min}$ & 3420 & 4175 & 138 \\
secretion & $(-17 \%)$ & $(-16 \%)$ & $(-32 \%)$ \\
\hline
\end{tabular}

${ }^{a}$ No basal output recorded.

gastrin release from each endocrine organ in response to the administration of exogenous secretin.

The gastrin concentration in the dog duodenal mucosa was approximately 0.0017 $\mu \mathrm{g} / \mathrm{g}$ mucosa, a value somewhat lower than that observed by Watson et al. [33]. Similar values of duodenal gastrin content, however, have been observed by Nilsson

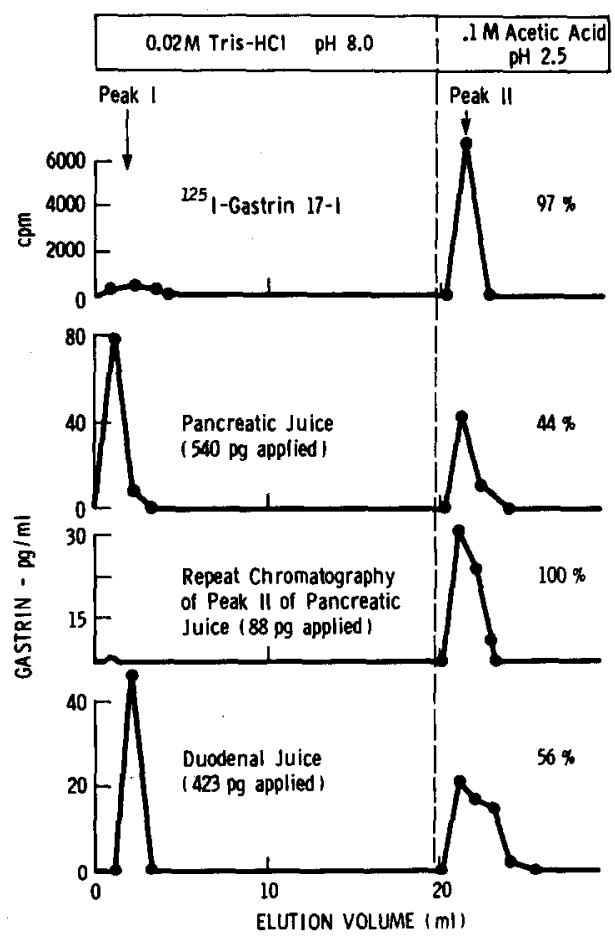

FIG. 8. The results of affinity chromotography of immunoreactive gastrin recovered from pancreatic and duodenal juice. 


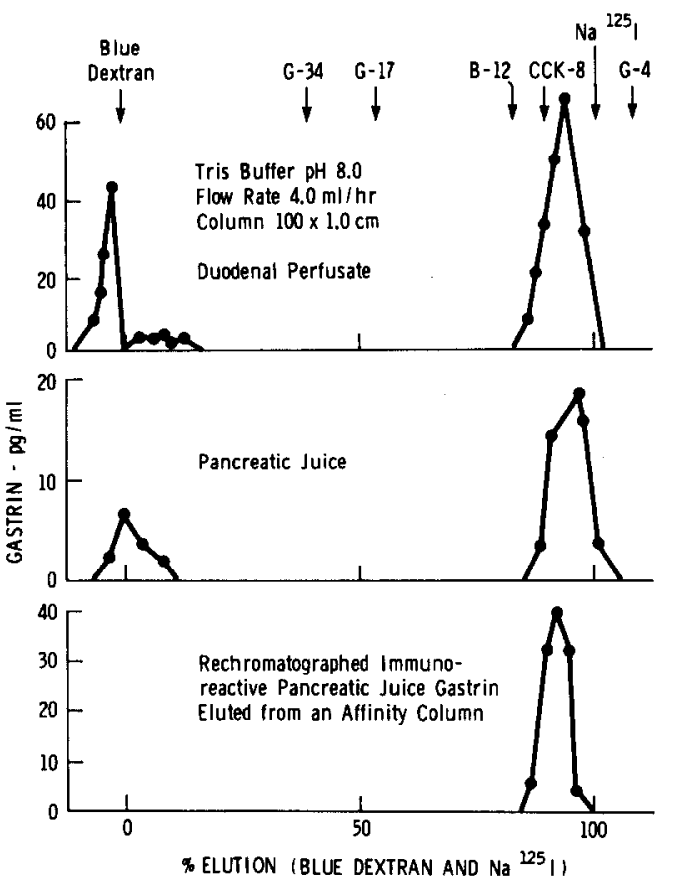

FIG. 9. Sephadex G50 superfine chromatography of immunoreactive gastrin in canine duodenal and pancreatic juice.

et al. and Uvnäs-Wallensten [22, 29]. Gastrin content in the dog pancreas was approximately $0.0008 \mu \mathrm{g} / \mathrm{g}$ tissue, $50 \%$ lower than that in duodenal tissue.

Immunoreactive gastrin was recovered in duodenal juice during basal and secretinstimulated periods. The lack of spontaneous juice flow (basal state) from the pancreatic duct precludes any comparative statements, but gastrin immunoreactivity was present in samples collected during secretin-stimulated periods. The elution patterns on gel filtration of pancreatic and duodenal juice samples indicated an immunoreactive gastrin-like peptide smaller than Rehfeld's component IV (G-14 or minigastrin [23, 24] and nearly equivalent in molecular size to CCK. ${ }^{8}$ Uvnäs-Wallensten et al. similarly observed gastrin release into the duodenal lumen of cats [29], but the peptide was not further characterized.

The concept of hormone release into the gut lumen has been viewed with skepticism, but several investigators have demonstrated gastrin-like peptides in gastric juice of man, dog, and cat $[1,8,13-15,30,32]$. In the cat, gastrin from gastric juice has been characterized by gel filtration as mainly G-17. The recovery from dog duodenal and pancreatic juice of a smaller gastrinlike peptide containing approximately eight of the carboxy-terminal amino acids of gastrin or CCK has not been reported. It is not surprising that gastrin-like peptides are recoverable from pancreatic juice. Lom-

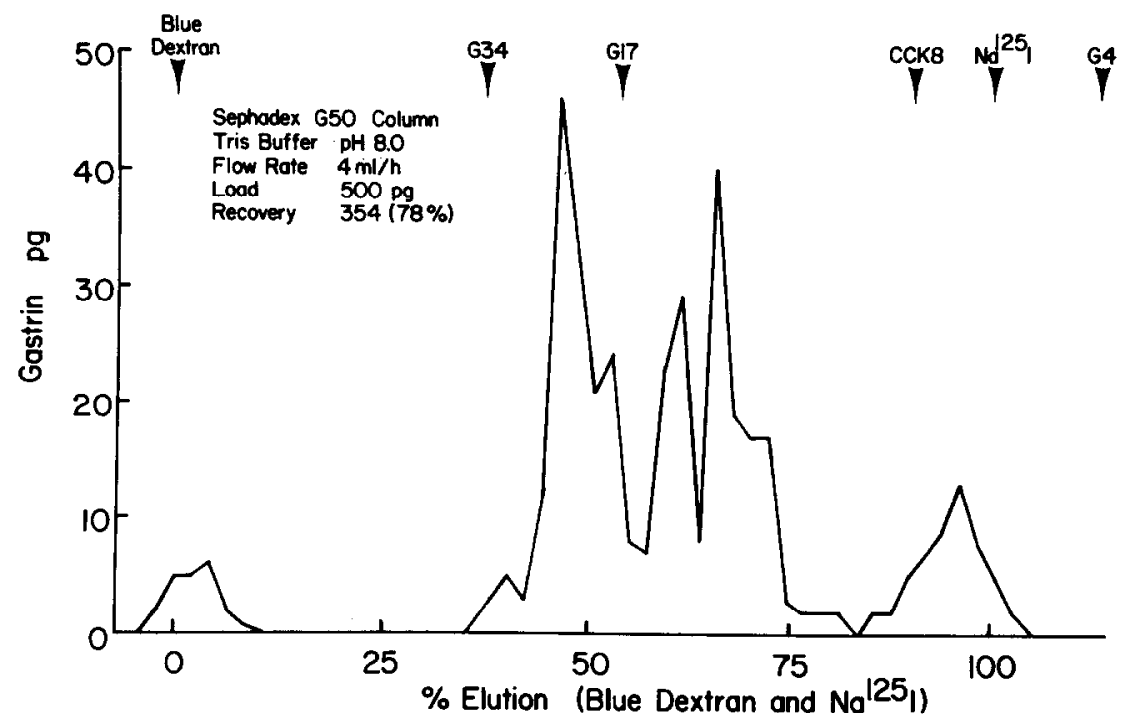

FIG. 10. Sephadex G50 superfine chromatography of immunoreactive gastrin in canine portal vein plasma. 
sky et al. [21] demonstrated in the human pancreas cells with gastrin-like immunoreactivity. This observation, however, has been disputed by others [3, 17]. True gastrin cells have been shown to occur in the pancreas and duodenum prenatally in human [17] and rat [18] species, but rarely are identifiable for longer than 2-3 weeks following birth. In addition, gastrinlike immunoreactivity to specific $\mathrm{C}$ terminalreacting gastrin antisera, although present in gastrinomas and prenatal pancreas, has not been demonstrated in adult pancreas [17]. These dissimilar observations, however, may be related to fixation problems, as pancreatic gastrin-producing $D$ or $A_{1}$ cells have histological and histochemical properties which differ from those of antral gastrin-producing $G$ cells and gastrinoma cells.

The administration of secretin to dogs and patients with "usual" forms of duodenal ulcer disease results in a fall or no change in fasting levels of circulating immunoreactive gastrin [28]. Circulating gastrin peptides in fasting man and dog have been characterized mainly as component II (G34) along with minute quantities of component IV (G-14) $[4,5,22,24,32]$. The infusion of 1,3 , and $5 \mathrm{U} / \mathrm{min}$ Boots secretin in our ex vivo preparation resulted in prompt increases in immunoreactive gastrin release into duodenal and pancreatic juice and, to a lesser degree, into portal venous blood as well. The quantities of gastrin released into duodenal juice were at least equal to, if not greater than, those released into portal venous blood (Table 1). The lesser rise in gastrin release at $5 \mathrm{U} / \mathrm{min}$ secretin into gut and pancreatic lumens as well as into portal venous blood suggests either a fatigue phenomenon or inhibition at the higher dose. In all experiments a 10 - to 15 min lag period preceded the spike increase in luminal gastrin release at each secretin infusion rate. A similar lag period preceding the fall in circulating gastrin levels in humans following secretin infusion has been observed by Korman et al. [16].
The increased levels of portal vein gastrin observed in the present study cannot be attributed solely to $\mathrm{pH}$ changes of the duodenal perfusate. Becker et al. [2] observed increases in regional venous gastrin release in response to perfusing the proximal duodenum of dogs with neutral or alkaline saline solutions. The constant acid orange color of duodenal effluent in all of the present experiments with dye indicator suggests that duodenal juice alkalinity was not a contributing factor.

The reason that others have not found that secretin is a stimulant for gastrin release may be due to measurements taken in the whole animal. Thompson et al. have shown that endogenous gastrin undergoes rapid extraction and degradation (35$37 \%$ per transit) in the small bowel of the dog [27]. Previous experiments (see Materials and Methods) showed that less than $8 \%$ of the immunoreactive gastrin in the total system is lost through dialysis per 30-min collection period, a cumulative loss of less than $25 \%$ for the entire study period. The lack in our system of an efficient mechanism for extraction and degradation of circulating gastrin may serve to explain the rise in portal vein gastrin levels following the infusion of secretin.

The concept of bidirectional release of hormone peptides into the gut lumen and regional venous circulation is not new. Fiddian-Green, Knight, and Vinik have demonstrated luminal gastrin release in man $[8,15,32]$, and Uvnäs-Wallensten et al. described bidirectional immunoreactive gastrin release from the antrum of anesthetized cats following vagal stimulation [30]. Solcia and colleagues have demonstrated two types of endocrine cells in gastric mucosa: Closed-type cells are limited to the gastric corpus and lack direct luminal communications; open-type cells, on the other hand, are found in the antrum and possess microvilli which project into the gastric lumen [26]. Ultrastructural studies of open-type cells indicates that their organization is appropriate not only for bidirectional hormone release but also 
for response to luminally active stimuli, including other hormones [19].

Our findings suggest further that bidirectional gastrin release may occur from extra-antral tissues. In the dog, secretin stimulation inhibits luminal release of antral gastrin and stimulates release from duodenum and pancreas in excess of that into portal venous blood. This phenomenon may also occur in the human but must be confirmed with further investigation. Ultrastructural studies of gastrinomas from patients with Zollinger-Ellison syndrome have shown the presence of nonuniform-appearing secretory cells which contain granules typical of antral $G$ cells [3]. In addition, ductular structures have been frequently observed in histologic sections of gastrinomas [3].

Gastrinoma cells are immunohistochemically similar to antral $G$ cells and react equivalently with carboxy terminal-directed gastric antisera [17]. The responses of gastrinoma cells and antral G cells to exogenous secretin, however, appear to differ markedly, suggesting that the two cell types are qualitatively dissimilar. However, following the administration of secretin in the dog, immunoreactive gastrin is released bidirectionally into pancreatic and duodenal juice as well as into portal venous blood. This observation implies that gastrin-producing $G$ or $D$ cells in the dog are functionally similar to the "open-type" gastric mucosal endocrine cells described by Solcias. If a similar pattern of gastrin release occurs in normal human subjects following secretin stimulation, one might anticipate negligible changes in circulating levels of gastrin because most of the gastrin appears in the intestinal lumen. Gastrinoma cells, on the other hand, may be morphologically distinct from normal gastrinproducing cells; they may be mainly "closedtype" cells with no communications with ductal structures. Secretin stimulation might then evoke apparent unidirectional release directly into portal venous blood. The variability in the magnitude but not the direction of gastrin responses to secretin in patients with Zollinger-Ellison syndrome may simply reflect differences in tumor size and "functional" gastrinoma cell mass.

\section{SUMMARY}

(1) Small peptides \pm eight or nine amino acids with gastrin-like immunoreactivity are found in duodenal and pancreatic juice in the dog.

(2) These peptides are released into the portal circulation in both basal and secretinstimulated states.

(3) Following secretin infusion in the dog, luminal gastrin release from extra-antral sites usually exceeds release into the portal circulation.

\section{SPECULATION}

(1) Gastrinoma cells and normal gastrinproducing cells may be morphologically distinct (closed versus open cell types) and differ in their communication with ductal structures.

(2) Hence, the administration of exogenous secretin to patients with gastrinomas (Zollinger-Ellison syndrome) may result in a unidirectional release of immunoreactive gastrin into the portal circulation, the magnitude of which depends on the mass of endocrinologically active tumor.

(3) These observations may serve to explain the paradoxical gastrin response to secretin in patients with gastrinomas.

\section{REFERENCES}

1. Anderson, S., and Nilsson, G. Appearance of gastrin perfusates from the isolated gastric antrum of dogs. Scand. J. Gastroenterol. 9: 619, 1974.

2. Becker, H. D., Reeder, D. D., and Thompson, J. C. Direct measurement of gastrin release from duodenum and jejunum in dogs. Amer. J. Physiol. 227: 897, 1974 .

3. Creuztfeldt, W., Arnold, R., Creutzfeldt, C., and Trach, N. S. Pathomorphologic, biochemical and diagnostic aspects of gastrinomas. Hum. Pathol. 6: 47,1975 .

4. Dockray, G. I., Debas, H. T., Walsh, J. H., and Grossman, M. I. Molecular forms of gastrin in antral mucosa and serum of dogs. Proc. Soc. Exp. Biol. N. Y. 149: 550, 1975.

5. Dockray, G. I., Walsh, J. H., and Passaro, E., 
Jr. Relative abundance of big and little gastrins in the tumors and blood of patients with ZollingerEllison syndrome. Gut 16: 353, 1975.

6. Edkins, J. S. The chemical mechanisms of gastric secretion. J. Physiol. 34: 133, 1906.

7. Fiddian-Green, R. G., Fink, A. S., and Vinik, A. I. Dual effect of luminal secretin on the release of antral gastrin in vitro. Clin. Res. 27: 632A, 1979 (abstract).

8. Fiddian-Green, R. G., and Vinik, A. D. The inhibitory actions of acid on the in vitro release of gastrin from human antral mucosa. S. Afr. J. Surg. 14: 79, 1976.

9. Gregory, R. A., and Tracy, H. J. The constitution and properties of two gastrins extracted from dog antral mucosa. Gut 5: 103, 1964.

10. Hayes, J. R., Johnson, D. G., Koerker, D., and Williams, R. H. Inhibition of gastrin release by Somatostatin in vitro. Endocrinology 96: 1374, 1975.

11. Jackson, B. M., Reeder, D. D., and Thompson, J. C. Dynamic characteristics of gastrin release. Amer. J. Surg. 123: 137, 1972.

12. Johnson, L. R., and Grossman, M. I. Intestinal hormones as inhibitors of gastric secretion. Gastroenterology 60: 120, 1971.

13. Jordan, P. H, and Yip, B. S. S. C. The presence of gastrin in fasting and stimulated gastric juice in man. Surgery 72: 352, 1972.

14. Jordan, P. H., and Yip, B. S. S. C. Origin of gastrin in gastric juice. Am. J. Surg. 128: 336 , 1974.

15. Knight, N. F., Fiddian-Green, K. G., and Vinik, A. I. In vivo release of gastrin into human gastric juice. Brit. J. Surg. 65: 118, 1978.

16. Korman, M. G., Soveny, C., and Hansby, J. Paradoxical effect of secretin on serum immunoreactive gastrin in Zollinger-Ellison syndrome. Digestion 8: 407, 1973.

17. Larsson, L. I., Hakanson, R., Sjoberg, N. O., and Sundler, F. Fluorescence histochemistry of the gastrin cell in fetal and adult man. Gastroenterology 68: 1152, 1975.

18. Larsson, L. I., Rehfeld, J. F., Sundler, F., and Hakanson, R. Pancreatic gastrin in fetal and neonatal rats. Nature (London) 262: 609, 1976.

19. Larsson, L. I., Sundler, F., and Hakanson, R. Pancreatic hormones in the gut and gut hormones in the pancreas. In T. Fujita (Ed.), Endocrine Gut and Pancreas. Amstcrdam: Elscvier, 1976. P. 133.

20. Lee, K. Y., Tai, H. H., and Chey, W. Y. Plasma secretin and gastrin responses to a meat meal and duodenal acidification in dogs. Amer. $J$. Physiol. 230: 784, 1976.

21. Lomsky, R., Langr, F., and Vortel, V. Immuno- histochemical demonstration of gastrin in mammalian islets. Nature (London) 223: 618, 1969.

22. Nilsson, G., Yalow, R. S., and Berson, S. A. Distribution of gastrin in the gastrointestinal tract of human, dog, cat and hog. Nobel Symposium XVI, Frontiers in Gastrointestinal Research. Almqvist and Wiksells, 1973. P. 95.

23. Rehfeld, J. F., and Stadil, R. Gel filtration studies on immunoreactive gastrin in serum from Zollinger-Ellison patients. Gut 14: 369, 1973.

24. Rehfeld, J. F., Stadil, F., Malstrom, J., and Miyata, M. Gastrin heterogeneity in serum and tissue. In J. C. Thompson (Ed.), Gastrointestinal Hormones. Austin and London: University of Texas Press, 1975. P. 43.

25. Ritchie, H. D., and Hardcastle, J. D. The isolated perfused canine pancreas. In H. D. Cooper and J. D. Hardcastle (Eds.), Isolated Organ Perfusion. Baltimore, Md.: University Park Press, 1973. P. 170.

26. Solcia, E., Capella, C., Vasallo, G., and Buffa, R. Endocrine cells of the gastric mucosa. Int. Rev. Cytol. 42: 223, 1975.

27. Thompson, J. C., Becker, H. D., Evans, J. C. W., Hjelmquist, U. B. E., Brandt, E. N., and Reeder, D. D. Studies in the catabolism of gastrin. In W. Y. Chey and F. P. Brooks (Eds.), Endocrinology of the Gut. Thorofare, N. J.: Charles B. Slack, 1974. P. 295.

28. Thompson, J. C., Reeder, D. D., Bunchman, H. H., Becker, H. D., and Brandt, E. N. Effect of secretin on circulating gastrin. Ann. Surg. 176: $384,1972$.

29. Uvnäs-Wallensten, K., Efendic, S., and Luft, R. Release of gastrointestinal hormones into the duodenal lumens of cats. Horm. Metab. Res. 10: 173, 1978.

30. Uvnäs-Wallensten, K., and Rehfeld, J. F. Molecular forms of gastrin in antral mucosa, plasma and gastric juice during vagal stimulation of anesthetized cats. Acta Physiol. Scand. 98: 217, 1976.

31. Vaysse, N., Bastie, M. J., Pascal, J. P., Roux, P., Martinel, C., Lacroix, A., and Ribet, A. Role of cholinergic mechanisms in response to secretin of isolated canine pancreas. Gastroenterology 69: 1269,1975 .

32. Vinik, A. I., Grant, B. J., and Novis, B. Gastrins in human antrum, duodenum and peripheral circulation. S. Afr. Med. J. (Suppl. S. Afr. J. Lab. Clin. Med.) 49: 255, 1975.

33. Watson, L. C., Reeder, D. D., Becker, H. D., LaGrone, L., and Thompson, J. C. Gastrin concentrations in upper gastrointestinal mucosa in dogs. Surgery 76: 419, 1974.

34. Yalow, R. S., and Berson, S. A. Size and charge distinctions between endogenous human plasma gastrin in peripheral blood and heptadecapeptide gastrins. Gastroenterology 58: 609, 1970. 